\title{
Research Study on Traditional Game Sports
}

\author{
Maryuni Maryuni ${ }^{1, *}$ Ahmad Nasrulloh ${ }^{1}$ \\ ${ }^{I}$ Postgraduate of Sports Science, Yogyakarta State University, Indonesia \\ "Corresponding author.Email: maryuni.2020@student.uny.ac.id
}

\begin{abstract}
Traditional sports are sports that come from cultural heritage or ancestral heritage that involve physical activity and movement. Traditional sports in each region have various types and ways of implementation. Traditional sport is one of the wealth and heritage that must be maintained and developed properly. The problems that occurred in previous studies have not examined the current barriers and developments of traditional sports. This study aims to describe the results of a literature study on traditional sports. This research is a literature review which is included in the type of qualitative research. The results of the literature review are expected to be used as studies or information that can be used as a theoretical basis for further research in traditional sports research. This research is important considering that traditional sports are now increasingly being forgotten or eroded by the times.
\end{abstract}

Keywords: Research Studies, Sports, Traditional.

\section{INTRODUCTION}

Sport is an activity that involves physical activity and motion in its implementation. Sport is one of the activities carried out to improve the quality of one's fitness [1]. Sport is a learning science that involves physical activity and motion. He continued, the sport aims to maintain and improve the quality of individual health [2]. Exercise is the right strategy to form a healthy body [3]. Sport is a physical activity that is carried out in leisure time on the basis of a desire or will that arises because it provides satisfaction or pleasure [4].

Sport itself has several sections that have been determined by law. Sports include educational sports, achievement sports, and recreational sports. Sports are divided into three namely achievement sports, education and recreation. Achievement sports are sports that are carried out with the aim of getting achievements. He continued to explain that this sport is more focused on training. Educational sports are sports that are included in the field of education. Recreational sports are sports that are done with the aim of getting pleasure when doing it. In Indonesia, stated in Law no. 3 of 2005 concerning the National Sports System was promulgated, there was a change in what was originally known as "community sports" to "recreational sports". This is stated in Article 17 which divides the scope of sports into three activities, namely educational sports, recreational sports, and achievement sports[5].
Recreational sport is one part of sports that is carried out voluntarily with the aim of getting enthusiasm and excitement after its implementation. Recreational sports are a type of sport that is carried out with the aim of getting fun and pleasure in its implementation. Widyaningsih explained that recreational sports are sports that are carried out by the wider community without any special training [6], [7]. It was explained that recreational sports are usually carried out with the aim of seeking pleasure and joy in their implementation. Recreational sports are part of sports that are carried out with the aim of making the body fresh and after doing it make the heart happy [8]. Recreational sports are part of the overall sport to obtain health, physical fitness and joy, to build social relationships. Preserving and increasing regional and national cultural wealth [9].

In organizing recreational sports that aim to provide pleasure after its implementation, one part of recreational sports in the community is traditional sports. Traditional sports are sports that people usually do. He continued, it was revealed that traditional sports are indigenous folk games which are national cultural assets that have elements of traditional physical exercise with or without supporting facilities, some of which are included in recreational sports [10]. The guidance and development of traditional recreational sports is carried out by exploring, developing, preserving, and utilizing traditional sports that exist in the community. Traditional sports are used to help people continue to carry out sports 
activities, even with sports originating from their respective regions or recreational sports being used [11].

Based on the description above regarding recreational sports and traditional sports which are part of achievement sports. This paper aims to conduct an indepth literature review on traditional sports. This research study will reveal about traditional sports based on the use of articles that have been published in journals. The results of this study are expected to provide an overview of traditional sports in Indonesia, so that it can be maximized in its application. The results of the study are also expected to provide an overview of how traditional sports in Indonesia are implemented, the existing obstacles in developing or implementing traditional sports and the advantages of traditional sports will be shown in the results and discussion study.

\section{METHOD}

This research is a type of literature review research which means it will examine the results of previous studies that reveal studies of traditional sports which are part of recreational sports. This research study will describe traditional sports which are recreational sports based on articles published in the last 7 years. This paper will discuss and examine this learning approach model by conveying each of its advantages and disadvantages as well as how it is applied and applied in this traditional sport activity. Furthermore, literature review research is included in the type of qualitative descriptive research. The data in this study were obtained through documents from previous studies which were collected by collecting and analyzing published scientific journal files. The discussion in this study will examine 15 articles related to traditional sports.

\section{RESULT AND DISCUSSION}

The results of the study will describe the articles studied regarding traditional sports. These articles are articles with the last 7 years of publication. This article is also indexed in each national and international indexing journal. To make it easier to read the results of this literature review, it can be seen in table 1 below:

Table 1. Results of the Collection of Indexed Journal Scientific Publication Articles Documents

\begin{tabular}{|c|c|c|}
\hline Penulis & Judul & Hasil \\
\hline $\begin{array}{l}\text { Edi Susrianto } \\
\text { Indra Putra }\end{array}$ & $\begin{array}{l}\text { Tradisi pacu jalur masyarakat } \\
\text { rantau kuantan (Studi Nilai- } \\
\text { nilai Budaya Melayu dalam } \\
\text { Olahraga Tradisional di } \\
\text { Kabupaten Kuantan Singingi) }\end{array}$ & $\begin{array}{l}\text { Indonesian } \\
\text { culture is closely } \\
\text { related to several } \\
\text { traditional sports. }\end{array}$ \\
\hline $\begin{array}{l}\text { Dindin } \\
\text { Bernhardin }\end{array}$ & $\begin{array}{lr}\text { Pengaruh } & \text { Olahraga } \\
\text { Permainan } & \text { Tradisional }\end{array}$ & $\begin{array}{l}\text { The traditional } \\
\text { sport of fighting }\end{array}$ \\
\hline
\end{tabular}

\begin{tabular}{|c|c|c|}
\hline & $\begin{array}{l}\text { Hadang terhadap Kelincahan } \\
\text { Siswa }\end{array}$ & $\begin{array}{l}\text { can improve } \\
\text { students' agility }\end{array}$ \\
\hline Supriyanto & $\begin{array}{l}\text { Peran permainan tradisional } \\
\text { dalam } \\
\text { pertumbuhan } \\
\text { perkembangan gerak anak } \\
\text { secara menyeluruh }\end{array}$ & $\begin{array}{l}\text { Traditional sports } \\
\text { are often used as a } \\
\text { type of game that } \\
\text { uses original } \\
\text { regional } \\
\text { characteristics } \\
\text { and is adapted to } \\
\text { local cultural } \\
\text { traditions. } \\
\text { Traditional sports } \\
\text { are felt to be able } \\
\text { to increase } \\
\text { people's interest } \\
\text { in sports }\end{array}$ \\
\hline $\begin{array}{l}\text { Annisa } \\
\text { Nasihatul Hana, } \\
\text { Setya Rahayu, } \\
\text { Siti } \\
\text { BaitulMukarro } \\
\text { mah }\end{array}$ & 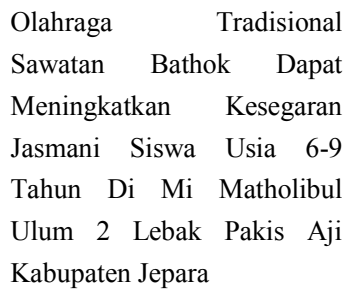 & $\begin{array}{l}\text { Traditional sports } \\
\text { can improve } \\
\text { students' physical } \\
\text { abilities }\end{array}$ \\
\hline $\begin{array}{l}\text { Novi } \\
\text { RachmawatiMu } \\
\text { hammad Muhyi } \\
\text {, Yoso Wiyarno }\end{array}$ & $\begin{array}{l}\text { Pengembangan Permainan } \\
\text { Olahraga Tradisional untuk } \\
\text { Meningkatkan Nilai Peduli } \\
\text { dalam Pembelajaran } \\
\text { Pendidikan Jasmani Olahraga } \\
\text { dan Kesehatan di Sekolah }\end{array}$ & $\begin{array}{l}\text { Traditional sports } \\
\text { that are applied to } \\
\text { students by } \\
\text { getting } \\
\text { modifications to } \\
\text { certain parts can } \\
\text { increase the value } \\
\text { of caring and } \\
\text { cooperation } \\
\text { between students. }\end{array}$ \\
\hline Agung Alaska & $\begin{array}{l}\text { Analisis Olahraga Tradisional } \\
\text { Lompat Tali Dan Engklek } \\
\text { Sebagai Peningkat Kebugaran } \\
\text { Tubuh Di Era New Normal }\end{array}$ & $\begin{array}{l}\text { Traditional sports } \\
\text { are able to } \\
\text { become one of } \\
\text { the alternative } \\
\text { sports that can be } \\
\text { done in the new } \\
\text { normal era. } \\
\text { Traditional sports } \\
\text { can also increase } \\
\text { an individual's } \\
\text { physical activity. }\end{array}$ \\
\hline $\begin{array}{l}\text { Novri Gazali, } \\
\text { Romi Cendra, } \\
\text { Yudi Putra }\end{array}$ & $\begin{array}{l}\text { Perkembangan Olahraga } \\
\text { Tradisional Pacu Jalur Di } \\
\text { Kabupaten Kuantan Singingi } \\
\text { Provinsi Riau }\end{array}$ & $\begin{array}{l}\text { Based on the } \\
\text { results of research } \\
\text { and discussion, it } \\
\text { can be concluded } \\
\text { that track racing } \\
\text { was awarded as } \\
\text { the most popular } \\
\text { tourism } \\
\text { destination in } \\
\text { Indonesia in the }\end{array}$ \\
\hline
\end{tabular}




\begin{tabular}{|c|c|c|}
\hline & & $\begin{array}{l}\text { Ministry of } \\
\text { Tourism's } \\
\text { Anugrah Pesona } \\
\text { Indonesia (API) } \\
\text { event. }\end{array}$ \\
\hline $\begin{array}{l}\text { Ztella } \\
\text { Rumawatine }\end{array}$ & $\begin{array}{l}\text { Identifikasi } \quad \text { Olahraga } \\
\text { Tradisional Di Kabupaten } \\
\text { Seram Bagian Barat }\end{array}$ & $\begin{array}{l}\text { Traditional sports } \\
\text { have decreased } \\
\text { interest in doing } \\
\text { so. He continued, } \\
\text { it was revealed } \\
\text { that this was due } \\
\text { to the times and } \\
\text { the absence of } \\
\text { socialization } \\
\text { regarding } \\
\text { traditional sports. }\end{array}$ \\
\hline $\begin{array}{lr}\text { Delvi } & \text { Kristanti } \\
\text { Liloi, } & \text { Yuniva } \\
\text { Yasin } & \end{array}$ & $\begin{array}{l}\text { Profil Olahraga Tradisional } \\
\text { Sanjasio }\end{array}$ & $\begin{array}{l}\text { The traditional } \\
\text { Sanjasio sport is a } \\
\text { form of sport in } \\
\text { the past by the } \\
\text { Kaili Njedu tribe } \\
\text { when the harvest } \\
\text { has arrived } \\
\text { known as } \\
\text { Kailinya Novonju } \\
\text { (pre-harvest } \\
\text { tradition) or } \\
\text { Nomparoya } \\
\text { (after-harvest } \\
\text { tradition) }\end{array}$ \\
\hline $\begin{array}{l}\text { Alwi Fahruzy } \\
\text { Nasution, } \\
\text { Dicky Edwar } \\
\text { Daulay }\end{array}$ & 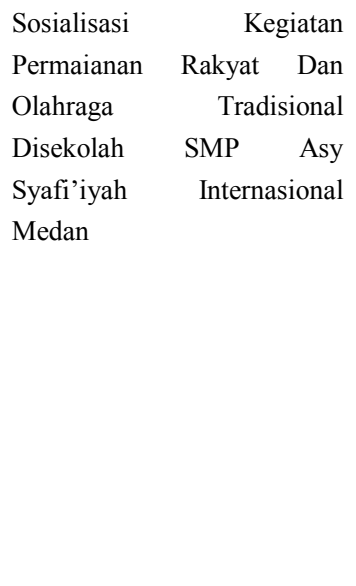 & $\begin{array}{l}\text { The need for } \\
\text { socialization } \\
\text { about traditional } \\
\text { sports and } \\
\text { community sports } \\
\text { to help develop } \\
\text { and increase } \\
\text { children's interest } \\
\text { in traditional } \\
\text { sports which can } \\
\text { also have an } \\
\text { effect on physical } \\
\text { fitness in learning } \\
\text { at school }\end{array}$ \\
\hline Ali Budiman & $\begin{array}{l}\text { Aktivitas Olahraga } \\
\text { Tradisional } \\
\text { pada Kalangan Re maja } \\
\text { di Mas a Pandemi } \\
\text { COVID-19 }\end{array}$ & $\begin{array}{l}\text { The lack of } \\
\text { interest and } \\
\text { activities carried } \\
\text { out by the } \\
\text { community for } \\
\text { traditional sports } \\
\text { is felt to be }\end{array}$ \\
\hline
\end{tabular}

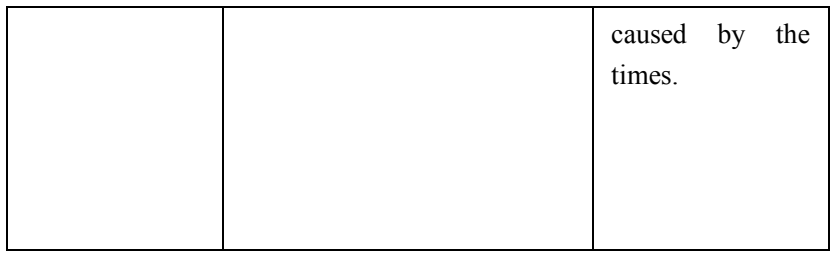

Traditional sports which are part of recreational sports are still very rarely discussed using the literature study method. The discussion of literature review research that discusses traditional sports in the published article, this discussion will explain the meaning of traditional sports, the development of traditional sports, barriers to traditional sports, the advantages of traditional sports. Furthermore, traditional sports conclusions will be drawn based on the results of previous studies that have been published in various reputable journals in the 2018-2021 range:

\subsection{Definition of Traditional Sports}

Traditional sports are sports that come from culture or heritage that are preserved in their implementation involving physical activity and movement. Traditional sports are done with the aim of getting happy after doing it. Traditional sports are sports that are carried out based on the existing culture [12]. In this study, the traditional sport that is focused on is horse racing. This sport is part of Malay culture which was later developed into a sport which involves movement activities so that after doing it, it gives the effect of body fitness. So it can be concluded that traditional sports are sports originating from remote areas of Indonesia which are passed down from generation to generation by word of mouth to their descendants which must be preserved, due to the establishment of an organization that oversees traditional sports games called KOT [13].

Traditional sports can include elements of its implementation: Popular games and children's games in it. maybe even with This includes activities that contain elements of art as it is known as traditionalist art. Traditional sports or traditional games are one of the physical activities that come from the culture of each region. One of the traditional sports that is good for children aged 6-9 years during their growth period is Sawatan Bathok [14]. Traditional sports are felt to be able to give a good effect and it is easy to do so and it is easy to find infrastructure in its implementation [15].

\subsection{Development of Traditional Sports}

Traditional sports originating from the cultural heritage of each region have their uniqueness and different implementations but are still in the unity of traditional sports. The development of sports which is a mixture of the culture of each region is still developing in life in society. Some facts in the field regarding the 
development of this traditional sport, some reveal that it is declining and stable or quite developed. Traditional sports or games have decreased in public interest [16]. The development of traditional sports needs a touch of technology so that they can compete or increase interest in doing these sports. The development of traditional sports in Indonesia is experiencing a boom, meaning that it is less attractive at the moment [17]. This is because traditional sports have been eroded by the era of globalization and involve technology in its application. Traditional sports are starting to be abandoned or their development is not good due to the lack of use of technology in its implementation. The results of his research revealed that out of $100 \%$, only $23 \%$ of teenagers did traditional sports [18].

\subsection{Barriers to the Development of Traditional Sports}

In the implementation of traditional sports or games, there are several obstacles and obstacles found in the field which result in the sinking or lack of interest in doing traditional sports. In line with this opinion, explained that the obstacles in the implementation of traditional sports were based on internal and external factors, then internal factors were revealed from within related to the desire to do sports without external encouragement. While the external factors include facilities and infrastructure supporting the implementation. Nasution \& Daulay explained that the biggest obstacles experienced in traditional sports are the lack of socialization of traditional sports to the community, the lack of public interest in exploring traditional wealth, and the lack of interest in competing in a tiered, sustainable, and sustainable manner. Manners [19].

The obstacle in developing these traditional sports and games is the lack of interest of teenagers or young people in implementing them. Technological factors and economic levels were obstacles in the traditional sport of stone jumping. The obstacles came from children who rarely knew traditional games, even those who did not know traditional games [20]. Change is the movement of the structure in question according to changes in time. In Indonesia, children actually have to be able to maintain this traditional game. The obstacle that occurs in the development of traditional games or sports is the lack of socialization about sports. He continued, it was revealed that nowadays parents are more likely to introduce or socialize sports or technology-based electronic media to their children.

\section{CONCLUSION}

Based on the explanation of the discussion of the literature review above in the relevance of previous research on traditional sports. Some of the discussions described in this study are about understanding, development, and obstacles in the field. The conclusion is that there is a need for internal and external attention and encouragement to traditional sports. The obstacles described are expected to be able to make references to be able to develop traditional sports so that they can compete with other sports. for further research, the author conveys and hopes for electronic media to be well used and able to improve softball learning achievement by conducting in-depth research reviews, perhaps focusing on traditional sports in one area or two specific areas or conducting an in-depth review of problem solving or obstacles found in the application of sports. traditional.

\section{REFERENCES}

[1] D. N. Wibawa, "Perlindungan Hukum Terhadap Atlet Pelatihan Daerah Dengan Organisasi Komite Olahraga Nasional Indonesia Terkait Kontrak Kerja,” Jurist-Diction, vol. 2, no. 6, pp. 2045-2060, 2019.

[2] B. F. T. Kuntjoro, "Rasisme Dalam Olahraga," J. Penjakora, vol. 7, no. 1, pp. 1-9, 2020.

[3] S. Salahudin and R. Rusdin, "Olahraga Meneurut Pandangan Agama Islam," JISIP (Jurnal Ilmu Sos. dan Pendidikan), vol. 4, no. 3, pp. 457-464, 2020, doi:

10.36312/jisip.v4i3.1236.

[4] Y. M. Tigor and R. M. Manikam, "Analisa dan Perancangan Aplikasi Pembentukan Komunitas Olahraga Berdasarkan Hobby Berbasis Web," ... (Jurnal Sist. Inf. dan E-Bisnis), vol. 2, pp. 351-363, 2021.

[5] M. B. Nababan, R. Dewi, and I. Akhmad, “Analisis Pola Pembinaan Dan Pengembangan Olahraga Rekreasi Di Federasi Olahraga Rekreasi Masyarakat Indonesia Sumatera Utara Tahun 2017," J. Pedagog. Olahraga, vol. 04, pp. 38-55, 2018.

[6] H. Widyaningsih H, "Model Outdoor Games Activities Untuk Pemuda Karang Taruna Tenaga Penggerak Olahraga Rekreasi. Faktultas Ilmu Olahraga. Universitas Negeri Jakarta," pp. 28-33, 2018.

[7] A. A. Kustiawan, "Memajukan olahraga rekreasi dan event olahraga sebagai upaya meningkatkan penjualan produk industri olahraga," J. Chem. Inf. Model., vol. 1, no. 1, pp. 74-82, 2018.

[8] K. Reza, ... B. K.-S. N. ke, and undefined 2019, "Analisis Motivasi Masyarakat Terhadap Olahraga Rekreasi Dalam Kegiatan Car Free Day di Simpang Lima Kota Semarang," Conference.Upgris.Ac.Id, pp. 27-32, 2019.

[9] T. Hidayat, M. Hudah, and U. H. Zhannisa, "Survey Minat Masyarakat Untuk Olahraga Rekreasi Bersepeda Pada Masa Pandemi Covid 
19 di Kabupaten Demak," J. Phys. Act. Sport., vol. 1, no. 1, pp. 80-88, 2020, doi: 10.53869/jpas.v1i1.17.

[10] A. H. Prastya and G. H. A. Susila, "Pemetaan Potensi Olahraga Rekreasi Di Kabupaten Buleleng - Bali," Penjakora, vol. 6, no. 2, pp. 127-132, 2019.

[11] J. M. Siahaan and Sundhari, "STUDI PEMANFAATAN HUMA BETANG TUMBANG MANGGU SEBAGAI SUMBER PEMBELAJARAN OLAHRAGA TRADISIONAL DI KALIMANTAN TENGAH," pp. 1-10, 2016.

[12] E. S. I. Putra, "TRADISI PACU JALUR MASYARAKAT RANTAU KUANTAN (Studi Nilai-nilai Budaya Melayu dalam Olahraga Tradisional di Kabupaten Kuantan Singingi)," $J$. OLAHRAGA INDRAGIRI, vol. 4, no. 1, pp. 2756, 2019.

[13] D. Bernhardin, "Pengaruh Olahraga Permainan Tradisional Hadang terhadap Kelincahan Siswa The Influence of Traditional Game Sports Barriers on Student Agility," J. Phys. Outdoor Educ., vol. 3, no. 1, pp. 79-85, 2021.

[14] Suprayitno, "PERAN PERMAINAN TRADISIONAL DALAM MEMBANTU PERTUMBUHAN DAN PERKEMBANGAN GERAK ANAK SECARA MENYELURUH," J. Ilmu Keolahragaan, vol. 17, no. 2, pp. 28-35, 2014.

[15] A. N. Hana, S. Rahayu, and S. B. Mukarromah, "OLAHRAGA TRADISIONAL SAWATAN BATHOK DAPAT MENINGKATKAN KESEGARAN JASMANI SISWA USIA 6-9 TAHUN DI MI MATHOLIBUL ULUM 2 LEBAK PAKIS AJI KABUPATEN JEPARA," J. Sport Sci. Fit., vol. 5, no. 2, p. 104, 2019.

[16] N. Rachmawati, M. Muhyi, and Y. Wiyarno, "Pengembangan Permainan Olahraga Tradisional untuk Meningkatkan Nilai Peduli dalam Pembelajaran Pendidikan Jasmani Olahraga dan Kesehatan di Sekolah Novi," J. Pendidik. Kesehat. Rekreasi, vol. 6, no. 2, pp. 125-137, 2020.

[17] Z. Rumawatine, "IDENTIFIKASI OLAHRAGA TRADISIONAL DI KABUPATEN SERAM BAGIAN BARAT," JARGARIA SPRINT J. Sci. Sport Heal., vol. 2, no. 1, pp. 17-30, 2020.

[18] Ali Budiman, “Aktivitas Olahraga Tradisional pada Kalangan Remaja di Masa Pandemi COVID-19," J. Phys. Outdoor Educ., vol. 3, no. 1, pp. 1-8, 2021, doi: 10.37742/jpoe.v3i1.84.

[19] A. F. Nasution and D. E. Daulay, "Sosialisasi Kegiatan Permaianan Rakyat Dan Olahraga
Tradisional Disekolah SMP Asy Syafi'iyah Internasional Medan," J. Liaison Acad. ..., no. 1, pp. 68-81, 2021.

[20] H. Yustinus Gulo, “Olahraga Tradisional Pemuda Lompat Batu,” vol. 64, pp. 10-14, 2021. 